\title{
THE PROCESS OF FORMATION OF THE ADHESIVE CAVITIES UNDER OSCILLATORY MOTION
}

\author{
PROCES FORMOWANIA SIĘ WŻERÓW ADHEZYJNYCH W RUCHU \\ OSCYLACYJNYM
}

\begin{abstract}
Key words:
wear testing, adhesion, oscillatory motion.

Abstract

Słowa kluczowe:

During the direct contact of metal-to-metal, complex tribological wear processes occur. One of the most important and the most problematic phenomena leading to irreversible changes in the geometric structure of the surface is adhesion as a result of a local welding of the asperity peaks. It causes local damage to the surface of the cooperating components in the form of the adhesive cavities. The paper presents the results of the wear tests, the purpose of which was to determine the impact of the surface geometry structure on the process of the adhesive wear and the formation of the adhesive cavities under oscillatory motion. The tests were carried out on the T-05 tribotester based on the previously established research plan. The geometrical surface structure was measured in the area of wear and the photographs of the adhesive cavities were made on an optical microscope. The captured images of a worn surface correspond to the images of the cavities presented in the literature. The obtained research results are the basis for the further development of a future research plan in a similar scope.

Streszczenie

badania zużyciowe, adhezja, ruch oscylacyjny.

Podczas bezpośredniego kontaktu metal-metal zachodzą złożone procesy zużycia tribologicznego. Jednym z najistotniejszych i najbardziej problematycznych zjawisk prowadzących do nieodwracalnych zmian struktury geometrycznej powierzchni jest adhezja jako skutek lokalnego zgrzewania występów nierówności. Powoduje ona powstawanie lokalnego uszkodzenia powierzchni elementów współpracujących w postaci wżerów adhezyjnych. W niniejszej pracy przestawiono wyniki badań z zużyciowych, których celem było określenie wpływu struktury geometrycznej powierzchni na proces zużywania adhezyjnego i tworzenia się wżerów adhezyjnych w ruchu oscylacyjnym. Badania zrealizowano na testerze T-05 w oparciu o założony wcześniej plan badawczy. Dokonano pomiaru struktury geometrycznej powierzchni w obszarze zużycia oraz wykonano fotografie wżerów adhezyjnych na mikroskopie optycznym. Zarejestrowane obrazy zużytych powierzchni odpowiadają swoim charakterem obrazom przedstawionym w literaturze. Uzyskane wyniki badań są podstawą do opracowania planu przyszłych badań w podobnym zakresie.
\end{abstract}

\section{INTRODUCTION}

Adhesive wear is one of the most serious types of tribological wear related to the surface layer of metals. Adhesive wear occurs under sliding motion (progressive or oscillating), most often during friction at low relative speeds and high pressures. It is well known that the occurrence and development of the adhesion depends on the degree of chemical affinity of metals, i.e. the higher the degree of chemical affinity, the greater is the tendency to adhesion. This is due to the impact of electrostatic forces caused by vibrations of surface atoms. Atoms can rotate, oscillate, and translate. Adhesive pull alone without creating bonds do not cause wear. Adhesive wear will occur when a protective film of adsorbed oxides is removed from the top layer and when the physical barrier of the metallic bond is overcome. Therefore, the tendency to form adhesive bonds is just

\footnotetext{
* Cracow University of Technology, Faculty of Mechanical Engineering, Jana Pawla II 37, 31-864 Cracow, Poland, e-mail: gkaczor@pk.edu.pl.
} 
one of the factors. The second is the tendency of the metal to produce layers of protective oxides.

In the work of selected authors, it can be noticed that the degree of the contamination of metallic surfaces also affects the development of adhesion. In work [L. 7], it was shown that reducing the contamination of the metal surface adversely affects the resistance against adhesion. The tests were carried out in a vacuum, and the material of the sample was iron, and the countersample was made of various materials [L. 8].

An important issue on the way to explain the physical nature of adhesion is the modelling of the adhesive wear mechanism. Authors of the work [L. 5] conducted simulation studies on the basis of a model that takes into account two controlled factors. In turn, the work [L. 11] presented the results of numerical analysis on the basis of the model of fractal surfaces in normal contact for given contact systems of asperity plastic deformation, wear rate on surface roughness, material properties, and the work of adhesion.

Some works relate to the friction and wear performance of selected lubricant materials under the sliding contact. They allow one to understand the friction wear behaviour of a cutting tool material [L. 3, $10,12,15]$. Researchers put their attention on the effect of carbide content and cobalt content, as the materials preferred for cutting tool applications on adhesive wear. They observed the worn surface after testing. Characteristic cavities appeared on the surface as the effect of the local damage of the top of asperities.

Intensive development of adhesive wear can lead to scuffing wear, which is a combination of adhesive and abrasive wear [L. 13]. This confirms the view expressed in [L. 1] about the fact that scuffing is initiated by local plastic deformations in the micro-regions of contact caused by the phenomenon of adhesion. The wear tests were carried out on a block-on-ring machine, which allows one to map the conditions of the operation of the friction couple with the piston ring and cylinder liner. On the basis of preliminary tests, the conditions for the main tests were adopted. It has been observed that the presence of nanoparticles in the lubricant limits the mechanism of the cavities formation. The material's resistance to the formation of the cavities is dependent on the temperature of the lubricant and the coefficient of friction. The occurrence of the adhesion phenomenon is cyclical. When the lubricant layer in the case of boundary lubrication is interrupted or when an unexpected loss of lubricant occurs from the friction junction, a sudden galling leading to the formation of cavities occurs [L. 9].

The focus on the plastic deformation of roughness peaks allowed, to some extent, to explain the mechanism of adhesive wear. The effect of cyclic contact stresses results in the separation of material particles on the roughness peaks. Ludema stated that these particles undergo displacement under the influence of a lubricant, cause a temperature increase at the interface between the elements, and lead to local damage of the protective lubricating layer. In addition, significant contact stresses contribute to the modification of the surface layer and promote the development of adhesive wear. For this reason, studies have been conducted on the role of protective layers formed from oxygen contained in the atmosphere or in lubricant molecules. The positive influence of protective layers on the increase of resistance against adhesive wear has been proved. The results of detailed studies show that both the strength and thickness of the protective layer are important [L. 9].

Based on the analysis of selected scientific studies, it can be concluded that an important stage in the development of adhesive phenomenon is the process of the formation of adhesion cavities. Therefore, the aim of the presented work is to study the development of adhesive cavities for various geometric structures of friction elements.

\section{EXPERIMENTAL DETAILS}

The wear tests were carried out using a T-05 tester, which has a block-on-ring couple (Fig. 1). The T-05 test machine consists of the block, fixed steady in the holder (4) by a hemispherical insert (3). The ring performs rotational motion according to the selected speed or oscillatory motion according to the selected frequency. A strain gauge force transducer force sensor (5) measures the motion resistance of the friction pair. The temperature of block and ring is measured by the thermocouples inserted in the special hole of the block [L. 16].

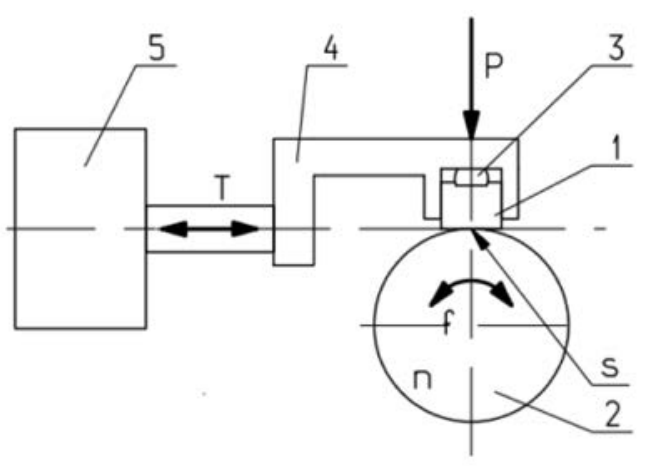

Fig. 1. Schematic view of the kinematic node in block-onring machine [L. 10]

Rys. 1. Schemat węzła kinematycznego w testerze T-05 [L. 10]

The material used to make the block and ring for these tests was steel S235, whose selected properties are shown in Table 1. Steel S235 is used to manufacture parts of machines and general-purpose components, wherever its characteristics are sufficient to fulfil the required 
functions. In the presented work, this type of material was deliberately chosen to make the probability of adhesion as large as possible. Furthermore, the similarity of the properties of the block and the ring material promotes the formation of adhesive bonds [L. 8].
In order to obtain a diversified surface structure of the block and ring, the surface of these elements has been treated by turning, milling, and grinding. The individual variants of the contacts are shown in Table 2.

Table 1. Mechanical properties of the S235 steel

Tabela 1. Wlaściwości mechaniczne stali S235

\begin{tabular}{|c|c|c|c|c|}
\hline Designation & $\operatorname{Re}[\mathbf{M P a}]$ & $\mathbf{R m}[\mathrm{MPa}]$ & HB [-] & $\mathbf{A}_{\mathbf{5}}[\mathbf{\%}]$ \\
\hline S235 & 235 & 410 & 140 & $21-24$ \\
\hline
\end{tabular}

Table 2. Variants of treatment for block and ring

Tabela 2. Warianty obróbki klocka i rolki

\begin{tabular}{|c|c|c|c|}
\hline \multirow{2}{*}{ Component } & \multicolumn{3}{|c|}{ Type of treatment } \\
\cline { 2 - 4 } & 1 & 2 & 3 \\
\hline block & grinding $(\mathrm{S})$ & milling $(\mathrm{T})$ & grinding $(\mathrm{S})$ \\
\hline ring & grinding $(\mathrm{S})$ & $\operatorname{turning}(\mathrm{T})$ & $\operatorname{turning}(\mathrm{T})$ \\
\hline
\end{tabular}

The research was carried out in oscillating motion due to the fact that, in this movement, the conditions for forming adhesive cavities are the most advantageous [L. 2], [L. 4]. The research plan was based on the work of other researchers and numerous preliminary tests performed by the author, during which the range of values of the test factors (P-force, oscillation amplitude, and oscillation frequency $\mathrm{f}$ ) were selected in a way to capture the development of the adhesive cavities. No lubricant was used in the test compound, because the intended goal of the project was to examine the phenomenon of physical adhesion. Conducting tests under lubricated conditions would cause that the development of proper wear would occur in a very long time $[\mathbf{L} . \mathbf{1}, \mathbf{4}, \mathbf{5}, \mathbf{6}]$.

During the tests carried out at an ambient temperature of approx. $20^{\circ} \mathrm{C}$, the friction force was measured by means of a strain gauge, while the block and ring temperature was measured using thermocouples

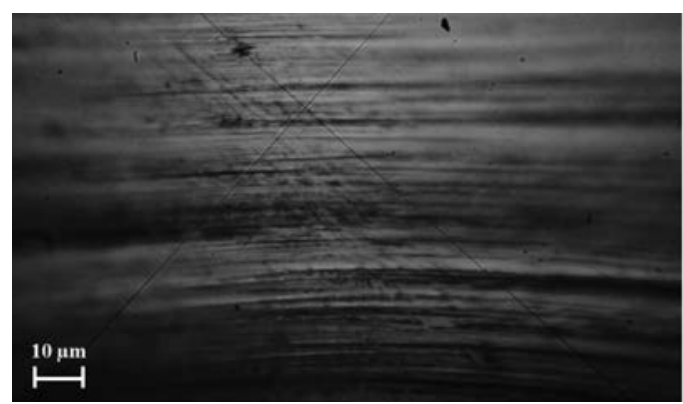

Fig. 2a. Surface view of the block before wear tests for the variant of ground block - ground ring

Rys. 2a. Widok powierzchni klocka przed badaniami zużyciowymi dla wariantu szlifowany klocek - szlifowana rolka applied to the special hole in the block. As a result of the tests, the temperature course of the block and ring and the coefficient of friction as a function of the number of cycles were obtained. The working cycle is understood as the deflection of the ring by a given value of the angle of oscillation and the return to the starting point.

The surface of the block and ring after wear tests were subjected to microscopic observation using an EPIQUANT optical microscope, and using a Taylor Hobson profilometer, and the geometric structure of the friction pair surface was measured.

\section{RESULTS AND DISCUSSION}

Before the wear tests for the assumed variants of the contacts, the surface of the block and ring were observed. The microscopic images of the surface of the block and ring before wear tests are shown in Figures 2-10.

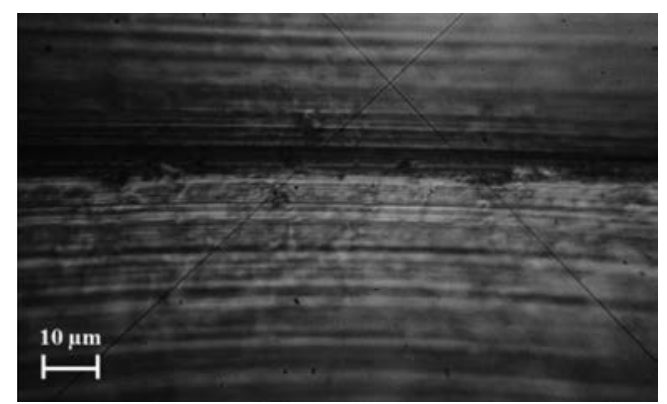

Fig. 2b. Surface view of the ring before wear tests for the variant of ground block - ground ring

Rys. 2b. Widok powierzchni rolki przed badaniami zużyciowymi dla wariantu szlifowany klocek - szlifowana rolka 


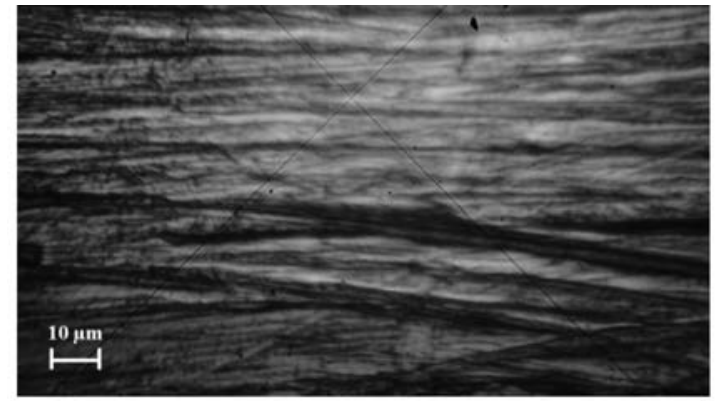

Fig. 3a. Surface view of the block before wear tests for the variant of milled block - turned ring

Rys. 3a. Widok powierzchni klocka przed badaniami zużyciowymi dla wariantu frezowany klocek - toczona rolka

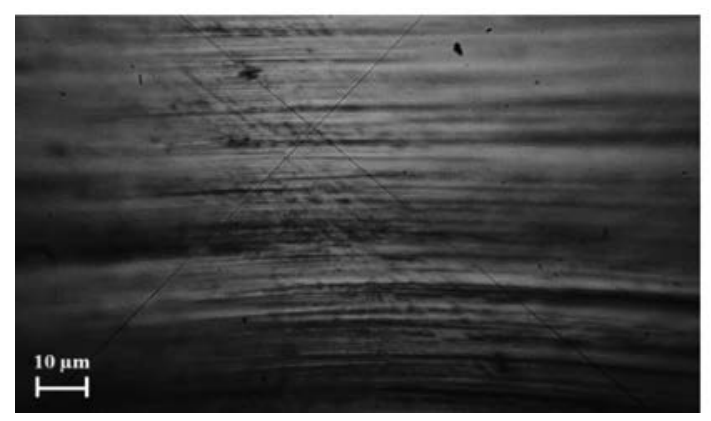

Fig. 4a. Surface view of the block before wear tests for the variant of ground block - turned ring

Rys. 4a. Widok powierzchni klocka przed badaniami zużyciowymi dla wariantu szlifowany klocek - toczona rolka

Tables 3a-3c summarize the values of the selected parameters of the surface roughness profile of the block and ring lead to the different variants of treatment.

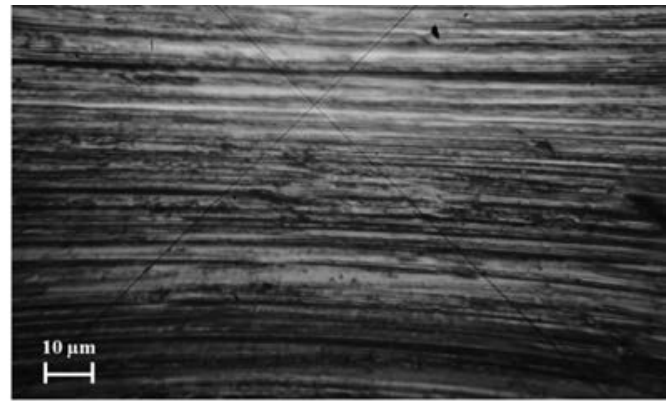

Fig. 3b. Surface view of the ring before wear tests for the variant of milled block - turned ring

Rys. 3b. Widok powierzchni rolki przed badaniami zużyciowymi dla wariantu frezowany klocek - toczona rolka

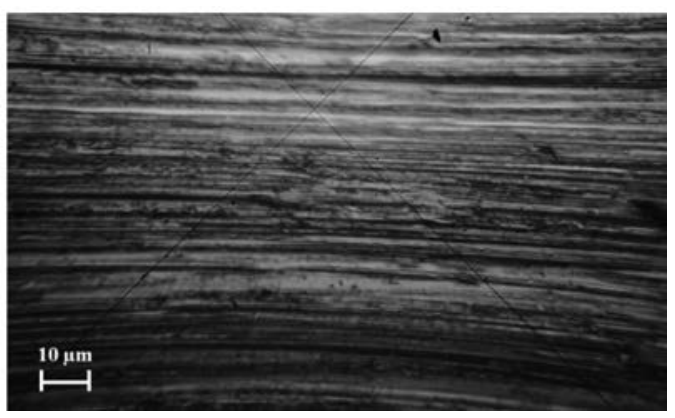

Fig. 4b. Surface view of the ring before wear tests for the variant of ground block - turned ring

Rys. 4b. Widok powierzchni rolki przed badaniami zużyciowymi dla wariantu szlifowany klocek - toczona rolka

Table 3a. $R_{a}$ parameter of the surface roughness profile of the variant of ground block - ground ring Tabela 3a. Parametr $\mathrm{R}_{\mathrm{a}}$ profilu chropowatości powierzchni dla wariantu szlifowany klocek - szlifowana rolka

\begin{tabular}{|c|c|c|}
\hline \multicolumn{3}{|c|}{ Parameters of the surface roughness } \\
\hline Designation & Block & Ring \\
\hline $\mathrm{R}_{\mathrm{a}(0.8)}$ & $0.50 \mu \mathrm{m}$ & $0.52 \mu \mathrm{m}$ \\
\hline
\end{tabular}

Table $3 \mathrm{~b} . \mathrm{R}_{\mathrm{a}}$ parameter of the surface roughness profile of the variant of milled block - turned ring Tabela 3b. Parametr $\mathrm{R}_{\mathrm{a}}$ profilu chropowatości powierzchni dla wariantu frezowany klocek - toczona rolka

\begin{tabular}{|c|c|c|}
\hline \multicolumn{3}{|c|}{ Parameters of the surface roughness } \\
\hline Designation & Block & Ring \\
\hline $\mathrm{R}_{\mathrm{a}(0.8)}$ & $3.05 \mu \mathrm{m}$ & $2.86 \mu \mathrm{m}$ \\
\hline
\end{tabular}

Table 3c. $R_{\mathrm{a}}$ parameter of the surface roughness profile of the variant of ground block - turned ring Tabela 3c. Parametr $\mathrm{R}_{\mathrm{a}}$ profilu chropowatości powierzchni dla wariantu szlifowany klocek - toczona rolka

\begin{tabular}{|c|c|c|}
\hline \multicolumn{3}{|c|}{ Parameters of the surface roughness } \\
\hline Designation & Block & Ring \\
\hline $\mathrm{R}_{\mathrm{a}(0.8)}$ & $0.49 \mu \mathrm{m}$ & $2.62 \mu \mathrm{m}$ \\
\hline
\end{tabular}


Figures 5a-5c show examples characteristic of selected physical quantities for particular variants: ground block - ground ring, milled block - turned ring, ground block - turned ring. The presented test results are only part of the whole research investigated and concern the assumed duration of the test (10000 cycles) under non-lubricated conditions, with the following values of the following parameters:

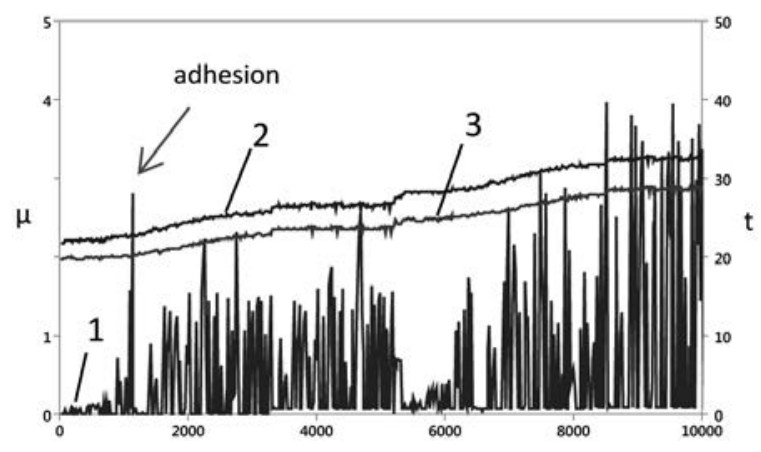

Fig. 5a. Characteristics of the variant ground block ground ring: 1 - friction coefficient, 2 - temp. of the block, 3 - temp. of the ring

Rys. 5a. Charakterystyki dla wariantu szlifowany klocek - szlifowana rolka: 1 - wsp. tarcia, 2 - temp. powierzchni klocka, 3 - temp. powierzchni rolki $-\operatorname{load} \mathrm{P}=0.33 \mathrm{~N}$,

- amplitude of oscillation $\alpha=10^{\circ}$,

- frequency of oscillation $\mathrm{f}=1 \mathrm{~Hz}$.

Figures $\mathbf{6 a - 6 c}$, in turn, refer to the surface images of the block and ring after performing the tests according to the above assumptions.

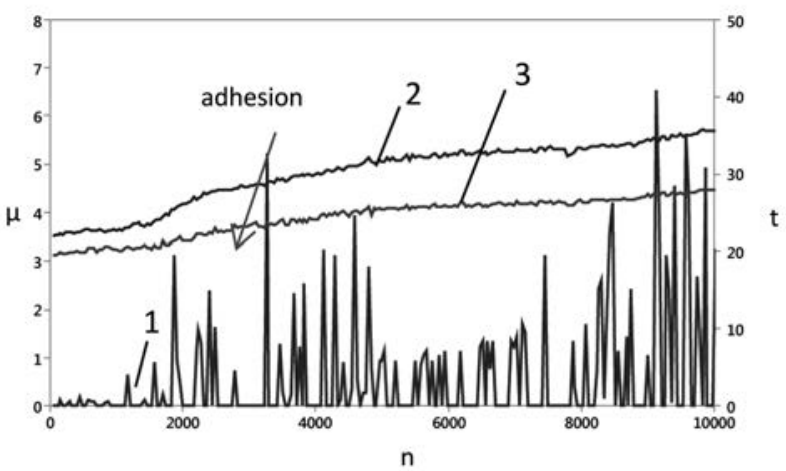

Fig. 5b. Characteristics of the variant milled block turned ring: 1 - friction coefficient, 2 - temp. of the block, 3 - temp. of the ring

Rys. 5b. Charakterystyki dla wariantu frezowany klocek - toczona rolka: 1 - wsp. tarcia, 2 - temp. powierzchni klocka, 3 - temp. powierzchni rolki

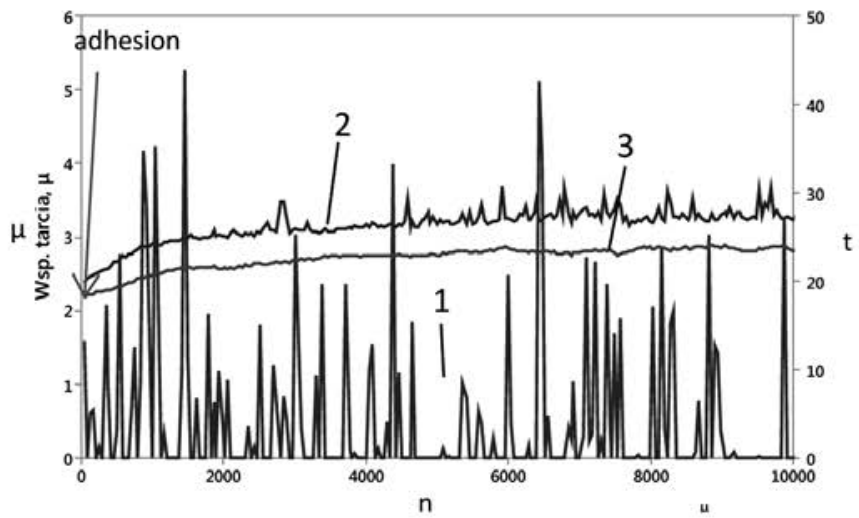

Fig. 5c. Characteristics of the variant ground block - turned ring: 1 - friction coefficient, 2 - temp. of the block, 3 - temp. of the ring

Rys. 5c. Charakterystyki dla wariantu szlifowany klocek - toczona rolka: 1 - wsp. tarcia, 2 - temp. powierzchni klocka, 3 - temp. powierzchni rolki

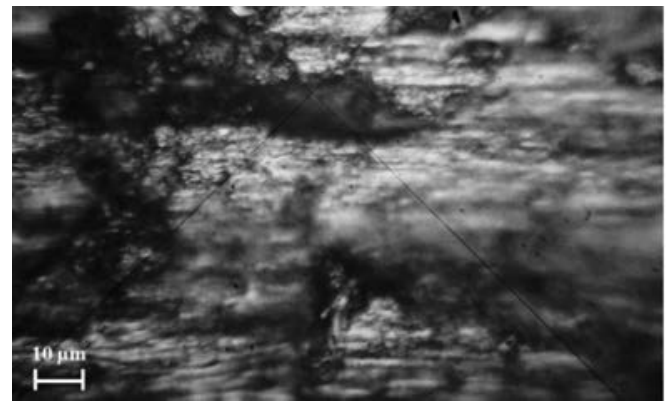

Fig. 6a. Image of the block's surface after wear tests for the variant of ground block - ground ring

Rys. 6a. Obraz powierzchni klocka po badaniach zużyciowych dla wariantu szlifowany klocek - szlifowana rolka

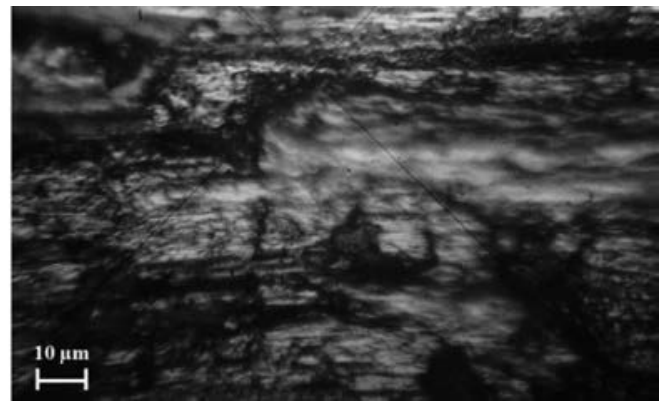

Fig. 6b. Image of the ring's surface after wear tests for the variant of ground block - ground ring

Rys. 6b. Obraz powierzchni rolki po badaniach zużyciowych dla wariantu szlifowany klocek - szlifowana rolka 


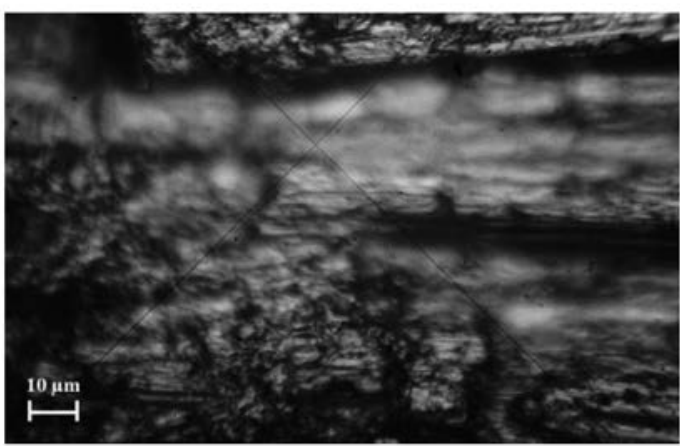

Fig. 7a. Image of the block's surface after wear tests for the variant of milled block - turned ring

Rys. 7a. Obraz powierzchni klocka po badaniach zużyciowych dla wariantu frezowany klocek - toczona rolka

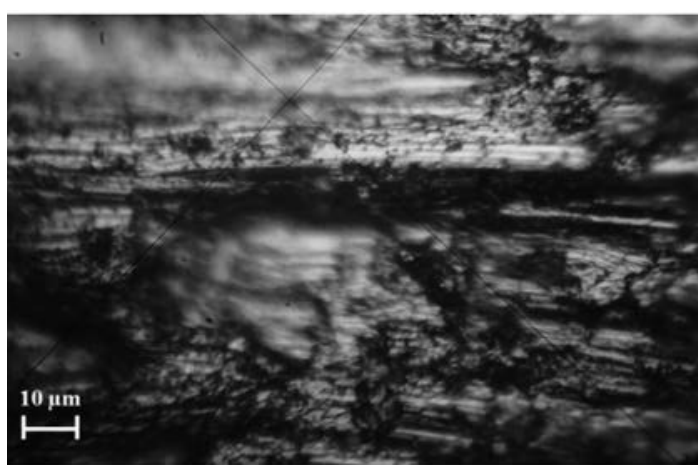

Fig. 8a. Image of the block's surface after wear tests for the variant of ground block - turned ring

Rys. 8a. Obraz powierzchni klocka po badaniach zużyciowych dla wariantu szlifowany klocek - toczona rolka

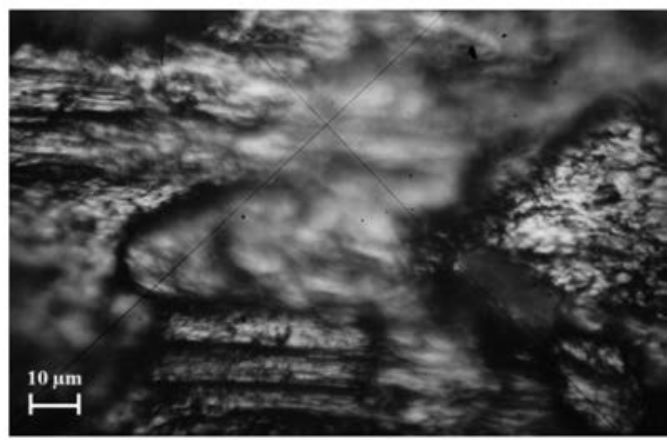

Fig. 7b. Image of the ring's surface after wear tests for the variant of milled block - turned ring

Rys. 7b. Obraz powierzchni rolki po badaniach zużyciowych dla wariantu frezowany klocek - toczona rolka

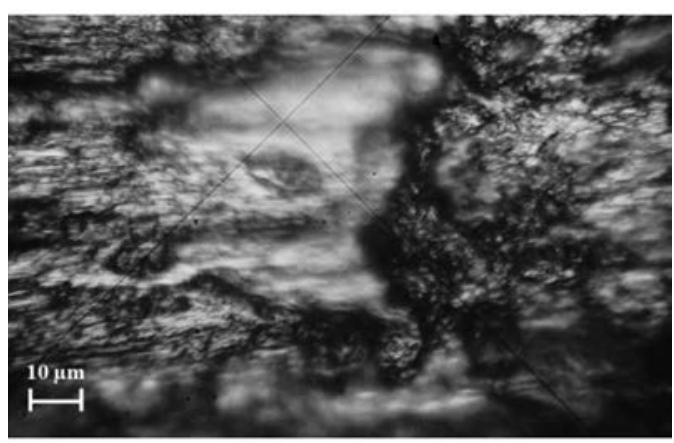

Fig. 8b. Image of the ring's surface after wear tests for the variant of ground block - turned ring

Rys. 8b. Obraz powierzchni rolki po badaniach zużyciowych dla wariantu szlifowany klocek - toczona rolka

Table 4a. $R_{a}$ and $R_{z}$ parameters of the surface roughness profile of the variant of ground block - ground ring after the wear tests

Tabela 4a. Parametry $\mathrm{R}_{\mathrm{a}}$ i $\mathrm{R}_{\mathrm{z}}$ profilu chropowatości powierzchni dla wariantu szlifowany klocek - szlifowana rolka, po badaniach zużyciowych

\begin{tabular}{|c|c|c|}
\hline \multicolumn{3}{|c|}{ Parameters of the surface roughness } \\
\hline Designation & Block & Ring \\
\hline $\mathrm{R}_{\mathrm{a}}$ & $3.71 \mu \mathrm{m}$ & $6.19 \mu \mathrm{m}$ \\
\hline $\mathrm{R}_{7}$ & $24.80 \mu \mathrm{m}$ & $31.40 \mu \mathrm{m}$ \\
\hline
\end{tabular}

Table $4 b . R_{a}$ and $R_{z}$ parameters of the surface roughness profile of the variant of milled block - turned ring after the wear tests

Tabela 4b. Parametry $R_{a}$ i $R_{z}$ profilu chropowatości powierzchni dla wariantu frezowany klocek - frezowana rolka, po badaniach zużyciowych

\begin{tabular}{|c|c|c|}
\hline \multicolumn{3}{|c|}{ Parameters of the surface roughness } \\
\hline Designation & Block & Ring \\
\hline $\mathrm{R}_{a}$ & $4.79 \mu \mathrm{m}$ & $10.20 \mu \mathrm{m}$ \\
\hline $\mathrm{R}_{\mathrm{r}}$ & $29.00 \mu \mathrm{m}$ & $62.40 \mu \mathrm{m}$ \\
\hline
\end{tabular}

Table 4c. $R_{a}$ and $R_{z}$ parameters of the surface roughness profile of the variant of ground block - turned ring after the wear tests

Tabela 4c. Parametry $\mathrm{R}_{\mathrm{a}}$ i $\mathrm{R}_{\mathrm{z}}$ profilu chropowatości powierzchni dla wariantu szlifowany klocek - toczona rolka, po badaniach zużyciowych

\begin{tabular}{|c|c|c|}
\hline \multicolumn{3}{|c|}{ Parameters of the surface roughness } \\
\hline Designation & Block & Ring \\
\hline $\mathrm{R}_{\mathrm{a}(0.8)}$ & $4.05 \mu \mathrm{m}$ & $7.67 \mu \mathrm{m}$ \\
\hline $\mathrm{R}_{\mathrm{r}(0 \mathrm{8})}$ & $22.00 \mu \mathrm{m}$ & $31.50 \mu \mathrm{m}$ \\
\hline
\end{tabular}


Based on the obtained images from the optical microscope (Figures 6-8) and the characteristics of the selected physical quantities (friction coefficient, the temperature of the block, the temperature of the ring), it can be stated that, during the wear tests, both abrasive and adhesive wear processes take place. The analysis of the current state of knowledge shows that, in the case of rapid increases in the value of the friction coefficient (Figures 5a-5c), we deal with the wear phenomena, among which adhesive wear predominates. The greater the stabilization of the friction coefficient, the greater is the share of abrasive wear. Therefore, for the further

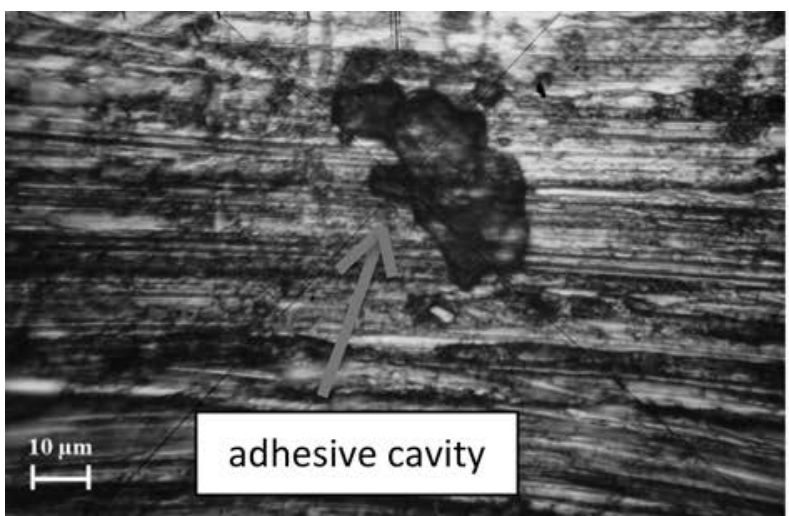

Fig. 9a. The image of the block's surface after repeating wear tests for the variant of a ground block ground ring

Rys. 9a. Obraz powierzchni klocka po powtórnych badaniach zużyciowych dla wariantu szlifowany klocek - szlifowana rolka

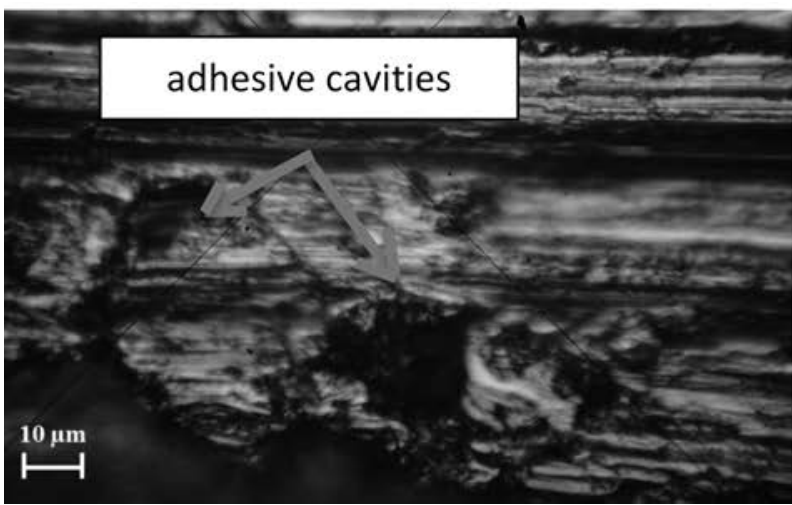

Fig. 10a. The image of the block's surface after repeating wear tests for the variant of a milled block turned ring

Rys. 10a. Obraz powierzchni klocka po powtórnych badaniach zużyciowych dla wariantu frezowany klocek - toczona rolka

In the sliding contact during the passage of liquid friction in dry friction, the risk of initiating the development of adhesive wear significantly increases. The speed of the development of this wear depends on studies of the formation of adhesive cavities under oscillating motion, the above-mentioned regularity was used. The wear tests for selected variants were repeated in the same conditions, assuming identical parameter values (load, amplitude of oscillation, frequency of oscillation). At the moment of the first clear increase in the value of the friction coefficient (marked with a red lined in Fig. 5a-5), the tests were stopped immediately, and then microscopic observations of the worn surface were made and compared with the results for the full test (10000 cycles). The results of the repeated tests are shown in Figures 9-11.

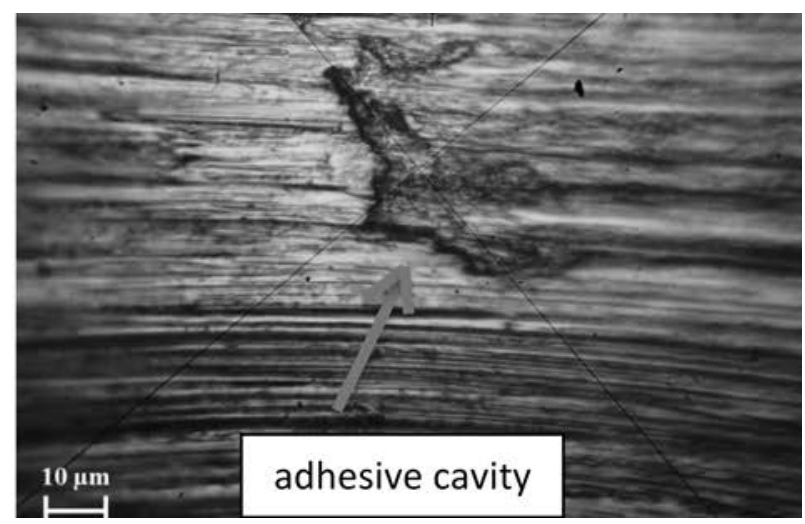

Fig. 9b. The image of the ring's surface after repeating wear tests for the variant of a ground block ground ring

Rys. 9b. Obraz powierzchni rolki po powtórnych badaniach zużyciowych dla wariantu szlifowany klocek - szlifowana rolka

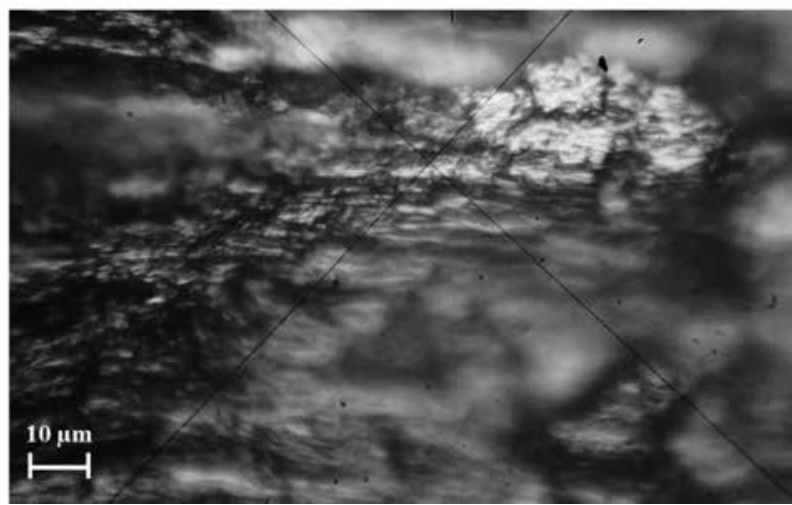

Fig. 10b. The image of the ring's surface after repeating wear tests for the variant of a milled block turned ring

Rys. 10b. Obraz powierzchni rolki po powtórnych badaniach zużyciowych dla wariantu frezowany klocek - toczona rolka

from the conditions of the cooperation of the friction couple (relative sliding speed, load, friction path), the materials used, and the geometric structure of the cooperating components. 


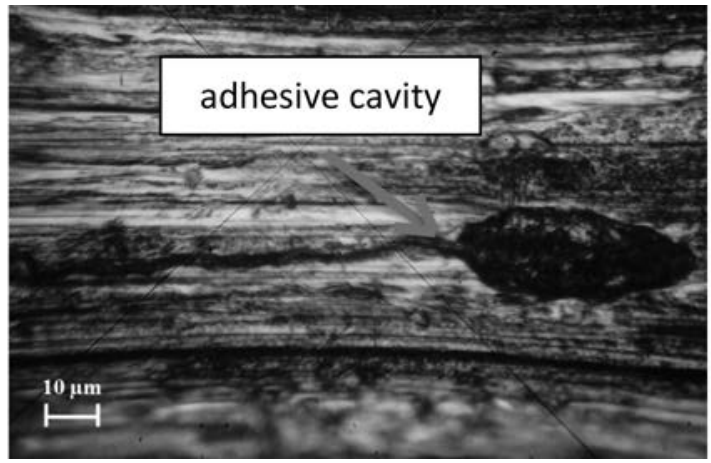

Fig. 11a. The image of the block's surface after repeating wear tests for the variant of a ground block turned ring

Rys. 11a. Obraz powierzchni klocka po powtórnych badaniach zużyciowych dla wariantu szlifowany klocek - toczona rolka

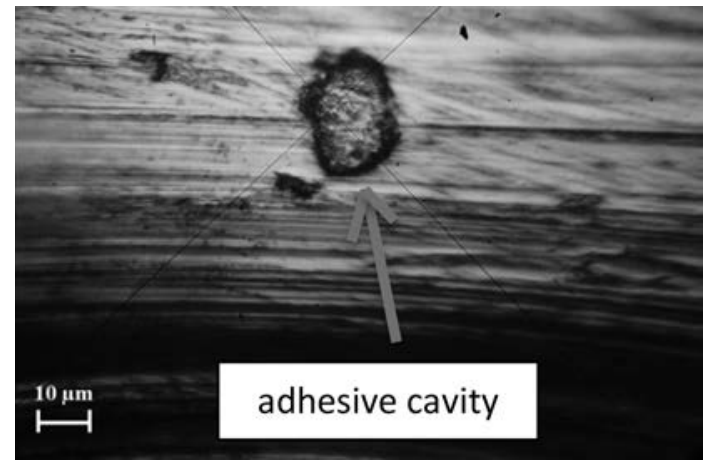

Fig. 11b. The image of the ring's surface after repeating wear tests for the variant of a ground block turned ring

Rys. 11b. Obraz powierzchni rolki po powtórnych badaniach zużyciowych dla wariantu szlifowany klocek - toczona rolka

Table 5a. $R_{a}$ and $R_{z}$ parameters of the surface roughness profile of the block and ring for the variant of ground block ground ring after the repeated wear tests

Tabela 5a. Parametry $\mathrm{R}_{\mathrm{a}}$ i $\mathrm{R}_{\mathrm{z}}$ profilu chropowatości powierzchni klocka i rolki dla wariantu szlifowany klocek - szlifowana rolka po powtórnych badaniach zużyciowych

\begin{tabular}{|c|c|c|}
\hline \multicolumn{3}{|c|}{ Parameters of the surface roughness } \\
\hline Designation & Designation & Designation \\
\hline $\mathrm{R}_{\mathrm{a}(0.8)}$ & $11.10 \mu \mathrm{m}$ & $5.34 \mu \mathrm{m}$ \\
\hline $\mathrm{R}_{\mathrm{z}(0.8)}$ & $5.50 \mu \mathrm{m}$ & $5.34 \mu \mathrm{m}$ \\
\hline
\end{tabular}

Table $5 b . R_{a}$ and $R_{z}$ parameters of the surface roughness profile of the block and ring for the variant of milled block turned ring after the repeated wear tests

Tabela 5b. Parametry $\mathrm{R}_{\mathrm{a}}$ i $\mathrm{R}_{\mathrm{z}}$ profilu chropowatości powierzchni klocka i rolki dla wariantu frezowany klocek - toczona rolka po powtórnych badaniach zużyciowych

\begin{tabular}{|c|c|c|}
\hline & \multicolumn{2}{|c|}{ Parameters of the surface roughness } \\
\hline Designation & Designation & Designation \\
\hline $\mathrm{R}_{\mathrm{a}(0.8)}$ & $8.81 \mu \mathrm{m}$ & $5.17 \mu \mathrm{m}$ \\
\hline $\mathrm{R}_{\mathrm{z}(0.8)}$ & $46.20 \mu \mathrm{m}$ & $35.90 \mu \mathrm{m}$ \\
\hline
\end{tabular}

Table 5c. $R_{a}$ and $R_{z}$ parameters of the surface roughness profile of the block and ring for the variant of ground block turned ring after the repeated wear tests

Tabela 5c. Parametry $\mathrm{R}_{\mathrm{a}}$ i $\mathrm{R}_{\mathrm{z}}$ profilu chropowatości powierzchni klocka i rolki dla wariantu szlifowany klocek - toczona rolka po powtórnych badaniach zużyciowych

\begin{tabular}{|c|c|c|}
\hline \multicolumn{3}{|c|}{ Parameters of the surface roughness } \\
\hline Designation & Designation & Designation \\
\hline $\mathrm{R}_{\mathrm{a}(0.8)}$ & $6.66 \mu \mathrm{m}$ & $4.33 \mu \mathrm{m}$ \\
\hline $\mathrm{R}_{\mathrm{z}(0.8)}$ & $32.3 \mu \mathrm{m}$ & $21.8 \mu \mathrm{m}$ \\
\hline
\end{tabular}

The real contact area is increased. It can be concluded that, at this stage, preparation for the development of adhesion starts. The next stage in the development of adhesive wear is the creation of single cavities as the effects of the destruction of adhesion bonds, which appear when the coefficient of friction increases rapidly. Therefore, the increase in the coefficient of friction may indicate a certain resistance of motion during the friction pair interaction caused by the formation and destruction of the adhesive bonds.

As the cooperation between the associated surfaces continues, the intensity of the separation of wear products increases, some of which is removed from the friction joint and some of it remains in it, creating the so-called 
"third body." It plays the role of abrasive wear, initially leading to the formation of micro scratches, whose direction is consistent with the direction of the motion of the friction couple. Continuous cooperation of friction couple leads to a temporary increase in the surface roughness, and then to its re-smoothing and increase in the real contact surface area. The rapid propagation of the phenomena described above into the surface layer results in permanent destruction of the cooperating surfaces, which is in line with the adhesive mashing model proposed by Nosal [L. 14]. The final consequence of the uninterrupted operation of the friction pair is the final form of wear - seizure.

\section{CONCLUSIONS}

The main purpose of the presented work was to examine the process of the formation of the adhesive cavities in the assumed research model. The obtained test results confirmed the presence of the adhesive cavities on the surface of the friction couple. The initiation of adhesive wear development is a sudden increase in the value of the friction coefficient caused by the breaking down the adhesive bonds. The formation of the adhesive cavities takes place irrespective of the type of surface treatment used. The technological layer before the tests becomes the operational layer after the wear tests. The obtained image of adhesive wear is in line with the image presented in the scientific papers by other researchers.

\section{REFERENCES}

1. Ajayi O.O., Lorenzo-Martin C., Erck R.A., Fenske G.R.: Analytical predictive modeling of scuffing initiation in metallic materials in sliding contact. Wear 301(1-2): 2013, pp. 57-61.

2. Bjerk R.O.: Oxygen-An "Extreme-Pressure Agent”. ASLE Trans 16(1973). Published by Tailor \& Francis. UK, 1973, pp. 97-106.

3. Bonny K., Beats P.D., Perez Y., Vlegels J., Lauwers B.: Friction and wear characteristics of WC-Co cemented carbides in dry reciprocating sliding contact. Wear 268(2010), pp. 1504-1517.

4. Cho D.H., Lee Y.Z., Comparision of scuffing life between unidirectional and reciprocating sliding motion. Wear 271, (2011), pp. 1637-1641.

5. Fukuda K., Morita T.: Physical model of adhesive wear in early stage of sliding. Wear 376-377 (2017), pp. $1528-1533$.

6. Guzowski S., Zając G., Kaczor G.: Scuffing tendencies of the tribological pairs under oscillatory motion. Tribologia. PIB w Radomiu, nr 5/2016, pp. 31-40.

7. Gwidon W., Stachowiak A., Batchelor W.: Engineering Tribology, Butterwotrh-Heinemann, 3-rd edition, Elselvier (1993), chapter 12, pp. 613-635.

8. Hebda M.: Procesy tarcia, smarowania i zużycia maszyn. Instytut Technologii Eksploatacji - PIB, Warszawa 2007.

9. Kaczor G.: Scuffing tendencies under the oscillatory motion. Doctoral thesis. Cracow University of Technology, Krakow 2018.

10. Kagnaya T., Boher C., Lambert L., Lazard M., Cutard T.: Wear mechanisms of WC-Co cutting tools from highspeed tribological tests. Wear 267 (2009), pp. 890-897.

11. Komvopoulos K.: An adhesive wear model of fractal surfaces in normal contact. International Journal and Structures 47 (2010), pp. 912-921.

12. Muthuraja A., Senthilvelan A.: Adhesive wear performance of tungsten carbide based solid lubricant material. International Journal of Refractory Metals and Hard Materials 52 (2015), pp. 235-244.

13. Michalczewski R., Piekoszewski W., Tuszyński W., Szczerek M., Wulczyński J.: The New Methods for Scuffing and Pitting Investigation of Coated Materials for Heavy Loaded, Lubricated Elements. Praca zbiorowa: Tribology - Lubricants and Lubrication (rozdz. 13, red. Chang-Hung Kuo), 2011, pp. 305-320.

14. Nosal S., Tribologiczne aspekty zacierania się węzłów ślizgowych. Poznań 1998.

15. Okonkwo P.C., Kelly G., Rolfe B.F., Pereira M.P.: The effect of temperature on sliding wear of steel-tool steel pairs. Wear 282-283(2012), pp. 22-30.

16. http://www.tribologia.eu/ptt/inst/rad/T-05_en.pdf. 